\title{
ANALISIS PENGARUH LIKUIDITAS DAN SOLVABILITAS TERHADAP PROFITABILITAS PADA PERUSAHAAN RETAIL TRADE YANG TERDAFTAR PADA BURSA EFEK INDONESIA TAHUN 2017-2019
}

\author{
Marcella Tabita Langkun, Fransisca Hanita Rusgowanto \\ Akuntansi, Universitas Bina Nusantara \\ marcella.tabita@binus.ac.id, fransisca.hanita@binus.ac.id
}

\begin{abstract}
Abstrak
Penelitian ini bertujuan untuk mengetahui pengaruh rasio likuiditas dan solvabilitas terhadap profitabilitas. Variabel yang diuji dalam penelitian ini terdiri dari variabel bebas yaitu likuiditas dan solvabilitas, dan variabel terikat yaitu profitabilitas. Jenis penelitian ini adalah penelitian kuantitatif. Populasi dalam penelitian ini adalah seluruh perusahaan perdagangan ritel yang terdaftar di Bursa Efek Indonesia. Sampel dalam penelitian ini berjumlah 33 sampel perusahaan retail trade yang digunakan terdaftar pada Bursa Efek Indonesia. Teknik analisis data yang digunakan adalah SPSS versi 25 dengan begitu Variabel dependen (Y) Profitabilitas memiliki nilai minimum -0,11, nilai maksimum 0,138. Variabel ini memiliki nilai rata-rata 0,03579 dan nilai standar deviasi 0, 041826. Variabel independen (X1) Likuiditas memiliki nilai minimum 0,017, nilai maksimum 2,801. Variabel ini memiliki nilai ratarata 0,78994 dan nilai standar deviasi 0,808678.Variabel independen (X2) Solvabilitas memiliki nilai minimum 0,158 , nilai maksimum 0,884 . Variabel ini memiliki nilai rata-rata 0,47158 dan nilai standar deviasi 0,214967, dengan nilai Adjusted $R$ Square adalah sebesar 0.439. Hal ini menunjukkan bahwa nilai koefisien determinasi dari penelitian ini adalah sebesar 0.439 dimana nilai tersebut menjelaskan sebesar $43.9 \%$ dengan variabel independen penelitian ini dapat menjelaskan variabel dependennya.

Kata Kunci: Likuiditas, Solvabilitas, Profitabilitas
\end{abstract}

\section{Abstract}

This study aims to determine the effect of liquidity and solvency ratios on profitability. The variables tested in this study consisted of independent variables, namely liquidity and solvency, and the dependent variable was profitability. This type of research is quantitative research. The population in this study are all retail trading companies listed on the Indonesia Stock Exchange. The sample in this study amounted to 33 samples of retail trade companies used listed on the Indonesia Stock Exchange. The data analysis technique used is SPSS version 25, so the dependent variable (Y) Profitability has a minimum value of -0.11, a maximum value of 0.138. This variable has an average value of 0.03579 and a standard deviation of 0.041826. The independent variable (X1) Liquidity has a minimum value of 0.017, a maximum value of 2.801. This variable has an average value of 0.78994 and a standard deviation of 0.808678 . The independent variable (X2) Solvency has a minimum value of 0.158, a maximum value of 0.884 . This variable has an average value of 0.47158 and a standard deviation of 0.214967 , with an Adjusted $R$ Square value of 0.439. This shows that the value of the coefficient of determination from this study is 0.439 where this value explains $43.9 \%$ with the independent variable of this study being able to explain the dependent variable.

Keywords: Liquidity, Solvency, Profitability 


\section{PENDAHULUAN}

Industri ritel diprediksi masih tertekan ke depan, mendorong dari sejumlah faktor, salah satunya konsumsi rumah tangga. Untuk mengatasi tekanan, sejumlah perusahaan ritel memiliki strategi dengan efisiensi, seperti menutup gerai dan melakukan pemutusan hubungan kerja (PHK). Salah satunya baru-baru ini dilakukan PT Hero Supermarket Tbk dengan menutup 26 gerai dan PHK 532 karyawan pada 2018. Institute for Development of Economics and Finance (INDEF) memperkirakan, hal tersebut masih akan berlanjut pada 2019 lantaran banyak faktor yang melatar belakanginya. Ekonom INDEF, Bhima Yudhistira Adinegara menilai, gejolak sektor bisnis ritel pada 2018 disebabkan karena pertumbuhan konsumsi rumah tangga terbilang stagnan."Retail masih tumbuh rendah tahun 2018 kemarin, karena pertumbuhan konsumsi rumah tangga enggak naik signifikan, rata-rata stagnan di 5 persen," ujarnya kepada Liputan6.com, Selasa 15 Januari 2020, pada kasus Hero Supermarket, ia melihat ada penurunan penjualan di bidang makanan hingga 6\%. Ia menuturkan, itu merupakan indikator adanya perlambatan konsumsi rumah tangga. Pada zaman seperti sekarang ini, persaingan antara perusahaan satu dengan yang lainnya untuk menjadi yang terbaik semakin ketat. Tujuan dari perusahaan adalah untuk medapatkan profit yang maksimal. Menurut Horne dan Wachowiz (2012) dalam bukunya Fundamentals of Financial Management telah di prinsip-prinsip manajemen keuangan dikatakan bahwa kemampuan memperoleh laba berbanding terbalik dengan likuiditas.

Carrefour dan Transmart mengadopsi inovasi-inovasi baru untuk tetap mempertahankan pasar. Salah satunya, memberikan fasilitas four in one, di mana masyarakat bisa belanja keperluan rumah tangga harian sambil berbelanja di department store, menghibur anak di mini trans studio, berkuliner, hingga melakukan layanan jasa perawatan pribadi. Sedangkan pada Perusahaan PT Ramayana Lestari Sentosa Tbk Setyadi Surya memandang tantangan yang ada di industri ritel saat ini lebih didominasi oleh unsur persaingan. Namun, berbeda dengan Satria, ia melihat faktor persaingan justru tak semata-mata karena kehadiran online, tetapi persaingan dengan sesama pemain ritel offline. Industri mempunyai peninggalan yang besar, pada tingkatan likuiditas mungkin hendak nyaman. Tetapi buat memperoleh keuntungan yang besar alam turun serta berakibat pada profitabilitas industri. Terus menjadi besar likuiditas, posisi industri di mata kreditur kian bagus sebab ada mungkin yang lebih besar kalau industri bisa melunasi kewajibannya pas durasi. Tetapi di bagian pemegang saham, likuiditas yang besar tidak senantiasa profitabel sebab berkesempatan memunculkan dana- dana yang menganggur yang sepatutnya dapat dipakai buat pemodalan dalam proyek- proyek yang profitabel industri.

Industri lebih banyak memakai hutang dibanding modal sendiri, hingga solvabilitas hendak terus menjadi besar sebab wajib dijamin pula hendak meningkat besar, serta bisa membuat profitabilitas sesuatu industri menyusut. Kemajuan gairah zona ritel pada tahun 2017 hingga dengan 2019 dalam penyusunan dari Wardhani mengatakan kalau zona ritel ialah zona yang mengaitkan produsen dengan kliennya. Zona ritel hendak senantiasa adadengan bentuk bidang usaha yang energik, menjajaki kemajuan teknologi dan style hidup. Dikala ini, kompetisi tidak cuma terjalin di ritel konvensional serta ritel modern, tetapi pula antara ritel konvensional yang menggunakan gerai raga serta ritel online. Ritel online mempunyai profit atas kemampuan yang dilahirkan. Di bagian lain, peritel konvensional sedang mempunyai kelebihan dibanding peritel online, ialah dari bidang pengalaman membeli- beli yang diperoleh oleh pelanggan. Dengan bertamu ke gerai raga, pelanggan bisa memandang produk yang diinginkannya. Aspek lain yang menaruh ritel konvensional di atas ritel online merupakan dari bidang prasarana. 


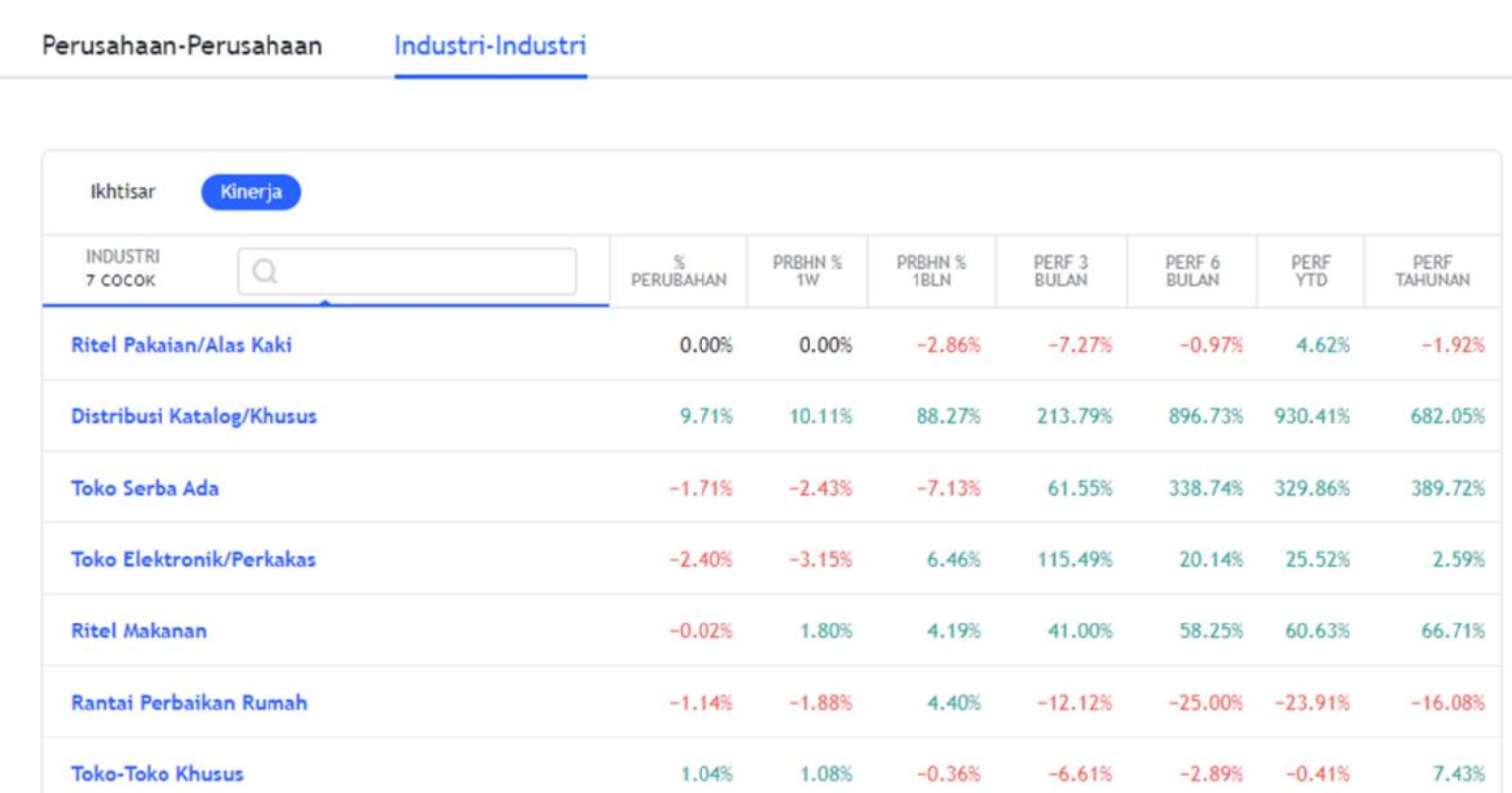

\section{Sumber : https://id.tradingview.com/markets/stocks-indonesia/sectorandindustry-sector/retail- trade/industries/}

Indonesia yang konsumen internet per jiwa dengan cara pada umumnya sedang lebih kecil dibanding dengan ASEAN, pasti zona ritel konvensional sedang mempunyai kemampuan, tidak hanya peneterasi internet yang kecil, prasarana peralatan pula jadi aspek yang menimbulkan lambatnya perkembagan ritel online. Salah satu tipe upaya ritel yang sedang amat menjanjikan merupakan merupakan minimarket, pergantian style hidup modern mendesak pelanggan lebih senang membeli- beli keinginan retail di tempat terdekat, tahun kemudian persisnya pada tahun 2019 minimarket sedang dapat berkembang $7 \%$ jauh melampaui hypermarket yang cuma dikisaran 3\%. Wiraswasta nampak lebih optimis di tahun ini, alasanya pasti sebab koreksi situasi ekonomi yang di proyeksikan menggapai 5, $1 \%$ hingga dengan 5, 5\%. Melonjaknya pemasukan warga, melonjaknya populasi masyarakat dengan tambahan demografi serta perkembangan warga yang cepat, urbanisasi, tingkatan optimisme pelanggan yang kokoh, serta perkembangan properti menguntungkan jadi permohonan pabrik ritel. Garis besar Consumer Confidence Report 2Q14 yang diluncurkan AC Nielsen membuktikan IKK Indonesia terletak pada tingkat 125 pada suku tahun IV 2017, di suku tahun III tahun 2017 bahakan luang terletak di nilai 127. Tadinya, IKK Indonesia apalagi menaiki posisi paling tinggi sepanjang 5 suku tahun beruntun di antara 60 negeri yang disurvei, walaupun turun namun IKK indonesia sedang menaiki posisi 3 besar Indikator Keyakinan Pelanggan Garis besar. Subjek industri yang dipakai dalam riset ini merupakan industri retail trade yang tertera di dalam Pasar uang Dampak Indonesia.Sebagai Negara yang membangun, pertumbuhan industri ritel Indonesia dipengaruhi oleh kekuatan daya beli masyarakat dan kebutuhan masyarakat akan pemenuhan produk konsumsi. Dengan memanfaatkan keadaan yang dapat dikatakan menjadi kebutuhan masyarakat, banyak investor yang ingin menginvestasikan dananya karena tingkat permintaan yang cukup tinggi, sehingga laba yang dihasilkan juga meningkat.

Likuiditas serta Profitabilitas silih berhubungan, disebabkan industri bisa penuhi kepekaan waktu pendek cakap memakai peninggalan lancarnya, hingga bisa dibilang kalau industri itu mempunyai lumayan anggaran yang ada buat melunasi liabilitasnya yang hendak berakibat pada profit untuk industri. Perbandingan Solvabilitas atau Leverage Perbandingan solvabilitas ataupun leverage ratio ialah perbandingan yang dipakai buat mengukur sepanjang mana aktiva industri dibiayai dengan pinjaman, maksudnya berapa besar bobot pinjaman pinjaman yang dijamin industri dibanding dengan aktivanya. Perbandingan solvabilitas ataupun leverage ialah perbandingan yang melukiskan sepanjang jauh sesuatu memakai pendanaan lewat pinjaman. Bersumber pada pada penjelasan diatas, hingga pengarang terpikat buat melaksanakan riset dengan kepala karangan" ANALISA PENGARUH LIKUIDITAS SERTA 


\section{SOLVABILITAS PERUSAHAAN RETAIL TRADE YANG TERDAFTAR PADA BURSA EFEK INDONESIA TAHUN 2017-2019".}

\section{TINJAUAN PUSTAKA \\ Teori Sinyal}

Teori sinyal (signaling theory) mengemukakan tentang bagaimana seharusnya sebuah perusahaan memberikan sinyal kepada pengguna laporan keuangan. Teori sinyal merupakan tanda yang diberikan oleh perusahaan kepada investor sebagai petunjuk tentang bagaimana memandang prospek perusahaan tersebut. Perusahaan dengan prospek yang menguntungkan akan menghindari penjualan saham dan akan mengusahakan modal baru dengan cara lain, salah satunya seperti dengan menggunakan hutang (Brigham dan Houston, 2014: 186).

\section{Laporan Keuangan}

Awalnya laporan keuangan bagi suatu perusahaan hanyalah sebagai alat penguji dari pekerjaan bagian pembukuan, tetapi untuk selanjutnya laporan keuangan tidak hanya sebagai alat penguji saja tetapi juga sebagai dasar untuk dapat menentukan atau menilai posisi keuangan perusahaan tersebut, di mana dengan hasil analisa tersebut pihak-pihak yang berkepentingan mengambil suatu keputusan. Laporan keuangan sendiri merupakan hasil proses akuntansi yang digunakan sebagai alat komunikasi dan gambaran kinerja perusahaan antara data keuangan atau aktifitas perusahaan dengan pihak-pihak yang berkepentingan dengan data tersebut.

\section{Likuiditas}

Menurut Fahmi (2015: 121) rasio likuiditas merupakan kemahiran sebuah perusahaan untuk melunasi utang jangka pendek tepat pada waktu. Contoh: pembayaran listrik, air, telepon, upah karyawan, teknisi maupun lembur dan lain-lain. Maka dari itu rasio likuiditas biasanya juga dinamakan sebagai short term liquidity. Jadi dapat disimpulkan rasio likuiditas adalah sebuah perusahaan yang dikatakan likuid apabila perusahaan mampu membayar semua kewajiban jangka pendeknya dengan aktiva lancar yang dimilikinya.

\section{Solvabilitas}

Menurut Hery (2016: 70) rasio solvabilitas disebut juga leverage adalah rasio yang dimanfaatkan dalam menilai sampai dimana aktiva suatu perusahaan dibiayai oleh kewajiban. Rasio solvabilitas disebut juga leverage dipakai dalam menghitung besarnya utang yang harus dibebankan oleh perusahaan pada kegiatan untuk memenuhi aset Penelitian yang diteliti, solvabilitas dihitung dengan memakai rasio debt to asset ratio (DAR). Pengukuran ini berguna menghitung dana yang disediakan kreditur seberapa jauhrumus Debt to Asset Ratio (DAR) adalah (Hanafi \& Halim, 2016: 79):

\section{DAR = Total Utang/Total Aset}

\section{Kerangka Pemikiran}

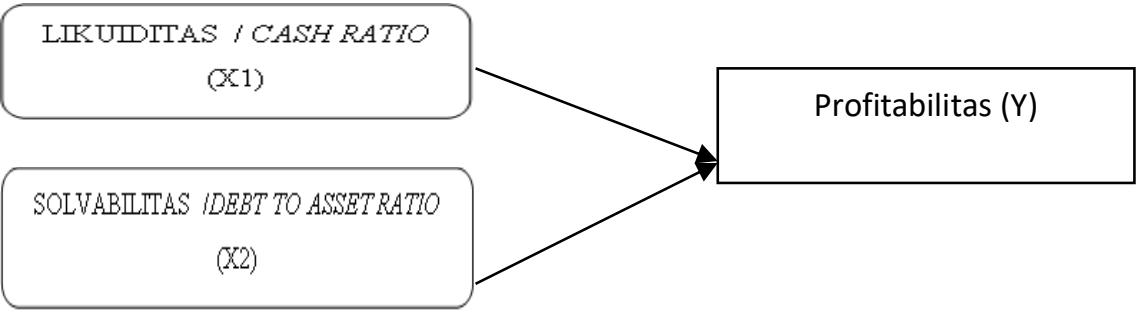

Berdasarkan pada kajian teori dan perumusan masalah, serta kerangka berpikir tersebut, maka hipotesis nol (H0) yang diajukan adalah:

$\mathrm{H}_{1}$ : Likuiditas berpengaruh terhadap Profitabilitas

$\mathrm{H}_{2}$ : Solvabilitas tidak berpengaruh terhadap Profitabilitas

\section{METODE PENELITIAN}

Penelitian ini menggunakan metode penelitian kuantitatif yang artinya analisis dalam penelitian ini menggunakan data-data dalam bentuk numerik. Sumber data yang digunakan dalam penelitian ini merupakan data sekunder yaitu laporan keuangan perusahaan retail trade yang terdaftar di Bursa Efek 
Indonesia yang dapat diakses melalui situs www.idx.co.id, website perusahaan yang bersangkutan dan sumber-sumber lainnya. Populasi penelitian ini adalah perusahaan retail tradeyang terdaftar di Bursa Efek Indonesia periode 2017-2019.

Metode pengumpulan sampel yang digunakan dalam penelitian ini adalah purposive sampling, yang harus dipenuhi dalam pemilihan sampel penelitian adalah sebagai berikut:

1.Perusahaan retail trade yang terdaftar di Bursa Efek Indonesia periode 2017-2019.

2.Perusahaan yang secara konsisten mempublikasi laporan keuangan selama periode 2017-2019.

3.Laporan keuangan perusahaan dalam satuan mata uang Rupiah.

Metode analisis data yang digunakan dalam penelitian ini adalah analisis regresi linear berganda dengan menggunakan software SPSS versi 25. Data yang sudah diperoleh dan dimasukkan ke tabulasi data akan diperoleh menggunakan uji statistik deskriptif, uji asumsi klasik dan uji hipotesis.

\section{HASIL DAN PEMBAHASAN}

Sampel yang digunakan penelitian ini berjumlah 33 sampel Berdasarkan tabel diatas, menunjukkan nilai DW sebesar 1.151. Nilai ini akan dibandingkan dengan nilai tabel D-W pada signifikansi 5\% dengan rumus $(\mathrm{k} ; \mathrm{N})$, adapun jumlah variabel independen $(\mathrm{k})$ adalah 2, sementara jumlah sampel $(\mathrm{N})$ adalah 33. Dari hasil diatas dapat disimpulkan bahwa hasil penelitian ini tidak terdapat autokorelasi.

\section{Analisis Statistik Deskriptif}

Analisis statistik deskriptif memberikan gambaran data sampel yang digunakan dalam penelitian ini sehingga dapat diketahui nilai rata-rata atau mean, nilai minimum, nilai maksimum dan standar deviasi dari masing-masing variabel. Hasil statistik deskriptif ditunjukkan dalam tabel 1 dibawah.

Tabel 1 Hasil Uji Statistik Deskriptif

\section{Descriptive Statistics}

\begin{tabular}{llllll} 
& $\mathrm{N}$ & Minimum & Maximum & Mean & Std. Deviation \\
\hline $\mathrm{X} 1$ & 33 & .017 & 2.801 & .78994 & .808678 \\
\hline $\mathrm{X} 2$ & 33 & .158 & .884 & .47158 & .214967 \\
\hline $\mathrm{Y}$ & 33 & -.011 & .138 & .03579 & .041826 \\
\hline Valid N (listwise) & 33 & & & & \\
\hline
\end{tabular}

\section{Sumber: Data Output SPSS 25}

Berdasarkan tabel 1 diatas, menunjukkan bahwa jumlah sampel yang digunakan dalam penelitian ini adalah sebanyak 33 sampel. Jumlah sampel tersebut berdasarkan hasil pemilihan sampel yang terdiri atas 11 perusahaan selama periode 3 tahun, dan hasil uji statistik deskriptif menunjukkan terdapat 2 variabel yaitu Likuiditas (X1) dan Solvabilitas (X2). Variabel dependen (Y) Profitabilitas memiliki nilai minimum $-0,11$, nilai maksimum 0,138 . Variabel ini memiliki nilai rata-rata 0,03579 dan nilai standar deviasi 0,041826. Variabel independen (X1) Likuiditas memiliki nilai minimum 0,017, nilai maksimum 2,801. Variabel ini memiliki nilai rata-rata 0,78994 dan nilai standar deviasi 0,808678. Variabel independen (X2) Solvabilitas memiliki nilai minimum 0,158 , nilai maksimum 0,884 . Variabel ini memiliki nilai rata-rata 0,47158 dan nilai standar deviasi 0,214967.

\section{Analisis Pengujian Asumsi Klasik}

\section{Uji Normalitas}

Uji normalitas dalam penelitian ini menggunakan metode Kolmogorov-Smirnov dengan kriteria pengambilan keputusan yaitu jika nilai Asymp. Sig (2-Tailed) $>0.05$, maka data terdistribusi normal. Berikut merupakan hasil olah data uji normalitas menggunakan Kolmogorov-Smirnov: 
Tabel 2 Hasil Uji Normalitas One-Sample Kolmogorov-Smirnov Test

\begin{tabular}{lll} 
& & $\begin{array}{l}\text { Unstandardized } \\
\text { Residual }\end{array}$ \\
\hline $\mathrm{N}$ & & 33 \\
\hline Normal Parameters & Mean & .0000000 \\
\cline { 2 - 3 } Most Extreme Differences & Std. Deviation & .03032214 \\
& Absolute & .134 \\
\cline { 2 - 3 } & Positive & .134 \\
\cline { 2 - 3 } & Negative & -.129 \\
\hline Test Statistic & & .134 \\
\hline Asymp. Sig. (2-tailed) & & $.143^{\mathrm{c}}$ \\
\hline
\end{tabular}

a. Test distribution is Normal.

b. Calculated from data.

c. Lilliefors Significance Correction.

\section{Sumber : Data Output SPSS 25}

Analisis uji normalitas dengan metode Kolmogorov-Smirnov ini dilihat dari nilai Asymp. Sig (2-tailed) yang menunjukkan nilai 0.143. Angka ini lebih besar dari 0.05 yang menunjukkan bahwa data terdistribusi normal dan layak digunakan untuk menguji tiap variabel.

\section{Uji Multikolinearitas}

Uji multikolinearitas bertujuan untuk menguji apakah dalam model regresi ditemukan adanya regresi antar variabel independen. Untuk menguji adanya multikolinearitas dalam penelitian ini, dapat dilihat dengan cara melihat nilai tolerance dan variance inflation factor (VIF). Batas dari nilai tolerance adalah > 0.1 dan batas nilai VIF < 10. Jika sudah memenuhi kriteria, maka dapat disimpulkan bahwa model regresi tersebut tidak terindikasi multikolinearitas. Berikut dapat dilihat hasil dari uji multikolinearitas dari penelitian ini adalah sebagai berikut:

\section{Tabel 3 Hasil Uji Multikolinearitas}

\section{Coefficients $^{\mathrm{a}}$}

\begin{tabular}{|c|c|c|c|c|c|c|c|c|}
\hline \multirow{3}{*}{$\frac{\text { Model }}{\text { (Constant }}$} & \multicolumn{2}{|c|}{ Unstandardized Coefficients } & \multirow{2}{*}{$\begin{array}{l}\text { Standardized } \\
\text { Coefficients } \\
\text { Beta }\end{array}$} & \multirow[b]{2}{*}{$\mathrm{t}$} & & \multirow[b]{2}{*}{ Sig. } & \multicolumn{2}{|c|}{ Collinearity Statistics } \\
\hline & $\mathrm{B}$ & Std. Error & & & & & Tolerance & VIF \\
\hline & .038 & .030 & & & 1.252 & .220 & & \\
\hline $\mathrm{X} 1$ & .025 & .012 & .480 & & 2.056 & .049 & 321 & 3.113 \\
\hline X2 & -.046 & .045 & -.237 & & -1.015 & .318 & .321 & 3.113 \\
\hline
\end{tabular}

Sumber : Data Output SPSS 25

Dapat diketahui dari hasil diatas bahwa nilai tolerance dari setiap variabel dalam penelitian ini lebih dari 0.1 dan nilai VIF kurang dari 10. Hal ini berarti tidak terjadi multikolinearitas antar variabel bebas atau dengan kata lain asumsi multikolinearitas terpenuhi.

\section{Uji Autokorelasi}

Pengujian autokorelasi akan dilakukan dengan menggunakan Durbin-Watson Test atau DW test. Berikut merupakan kriteria yang memiliki ketentuan sebagai berikut:

1. Angka DW dibawah -2 berarti ada autokorelasi positif

2. Angka DW diantara -2 sampai +2 berarti tidak ada autokorelasi

3. Angka DW diatas +2 berarti ada autokorelasi negatif. 
Tabel 4 Hasil Uji Autokorelasi Model Summary ${ }^{\mathrm{b}}$

\begin{tabular}{ll|llll} 
& & & Adjusted & \multicolumn{2}{c}{ RStd. Error of the } \\
Model & R & R Square & Square & Estimate & Durbin-Watson \\
\hline 1 & $.689^{\mathrm{a}}$ & .474 & .439 & .031317 & 1.151 \\
\hline
\end{tabular}

a. Predictors: (Constant), X2, X1

b. Dependent Variable: Y

\section{Sumber : Data Output SPSS 25}

Berdasarkan tabel diatas, menunjukkan nilai DW sebesar 1.151. Nilai ini akan dibandingkan dengan nilai tabel D-W pada signifikansi 5\% dengan rumus $(\mathrm{k} ; \mathrm{N})$, adapun jumlah variabel independen (k) adalah 2, sementara jumlah sampel $(\mathrm{N})$ adalah 33. Dari hasil diatas dapat disimpulkan bahwa hasil penelitian ini tidak terdapat autokorelasi.

\section{Uji Heteroskedastisitas}

Uji heteroskedastisitas dapat dilakukan dengan metode scatterplot yaitu dengan melihat hasil suatu grafik. Berikut adalah hasil scatterplot dalam penelitian ini:

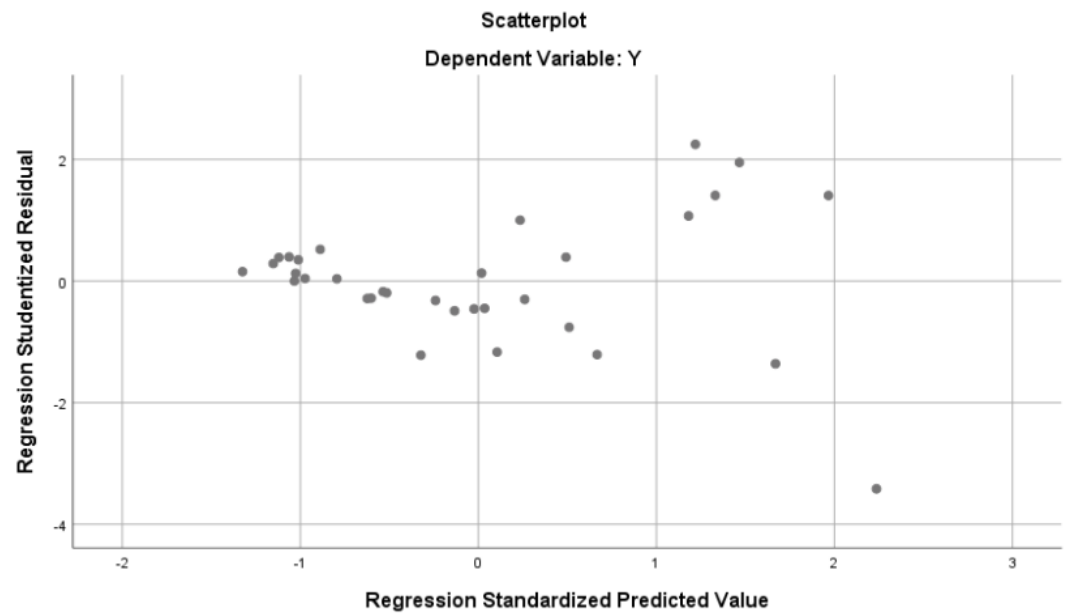

Gambar 1. Hasil Uji Heteroskedastisitas

Dari gambar diatas, dapat dilihat bahwa titik-titik menyebar secara acak dan tidak membentuk pola tertentu. Maka dari itu, dapat disimpulkan bahwa dalam penelitian ini tidak terjadi heteroskedastisitas pada model persamaan regresi linear baik berdasarkan uji glejser ataupun dilihat dari grafik scatterplot.

Uji Hipotesis

Analisis Regresi Linear Berganda

\section{Tabel 7 Hasil Uji Regresi Linear Berganda}

\section{Coefficients $^{\mathbf{a}}$}

\begin{tabular}{|c|c|c|c|c|c|}
\hline & Unsta & Coefficients & $\begin{array}{l}\text { Standardized } \\
\text { Coefficients }\end{array}$ & & \\
\hline Model & $\mathrm{B}$ & Std. Error & Beta & $\mathrm{t}$ & Sig. \\
\hline 1 (Constant) & .038 & .030 & & 1.252 & .220 \\
\hline $\mathrm{X} 1$ & .025 & .012 & .480 & 2.056 & .049 \\
\hline $\mathrm{X} 2$ & -.046 & .045 & -.237 & -1.015 & .318 \\
\hline
\end{tabular}

a. Dependent Variable: Y

\section{Sumber : Data Output SPSS 25}

Berdasarkan tabel diatas persamaan regresi linear berganda dapat disusun sebagai berikut: $\mathrm{Y}=0.038+$ $0.025 \mathrm{X} 1+-0.046 \mathrm{X} 3+\mathrm{e}$ 


\section{Uji T}

Uji t memiliki tujuan untuk menunjukkan seberapa jauh pengaruh variabel independen terhadap variabel dependen secara parsial. Pengambilan keputusan berdasarkan nilai sig. $<0.05$, maka variabel independen memiliki pengaruh secara parsial terhadap variabel dependennya. Begitu juga sebaliknya, jika nilai sig. > 0.05 maka variabel independen tidak berpengaruh secara parsial terhadap variabel dependennya. Berdasarkan tabel 7 diatas, ditarik kesimpulan sebagai berikut: Variabel Likuditas memperoleh nilai $\mathrm{T}_{\text {hitung }}$ sebesar 2,056 dan nilai $T_{\text {tabel }}$ sebesar 1,697, dan nilai tingkat signifikan sebesar 0,049. Karena tingkat signifikan lebih kecil dari $\alpha=0,05$, maka terdapat pengaruh variabel likuiditas terhadap variabel profitabilitas. Variabel Solvabilitas memperoleh nilai $t_{\text {hitung }}$ sebesar -1,015, dan nilai $\mathrm{T}_{\text {tabel }}$ sebesar 1,697, dan tingkat signifikan sebesar 0,318 . Karena tingkat signifikan lebih besar dari $\alpha=0,05$, maka tidak terdapat pengaruh variabel solvabilitas terhadap variabel profitabilitas.

\section{2. $\mathbf{U j i} \mathbf{F}$}

Uji $F$ penelitian ini dilakukan untuk melihat signifikansi pengaruh secara simultan variabel independen penelitian terhadap variabel dependennya. Pengujian ANOVA adalah salah satu uji perbandingan yang digunakan untuk menguji perbedaan rata-rata data lebih dari dua kelompok. Pengambilan keputusan berdasarkan nilai sig. $<0.05$, maka variabel independen memiliki pengaruh secara simultan terhadap variabel dependennya. Begitu juga sebaliknya, jika nilai sig. $>0.05$ maka variabel independen tidak berpengaruh secara simultan terhadap variabel dependennya. Berikut terlampir tabel hasil penelitian uji F.

Tabel 8 Hasil Uji F

ANOVA $^{\mathrm{a}}$

\begin{tabular}{lllllll} 
Model & Sum of Squares & df & Mean Square & F & Sig. \\
\hline Regression & .027 & 2 & .013 & 13.541 & $.000^{\mathrm{b}}$ \\
\hline Residual & .029 & 30 & .001 & & \\
\hline Total & .056 & 32 & & & \\
\hline
\end{tabular}

a. Dependent Variable: Y

b. Predictors: (Constant), X2, X1

\section{Sumber : Data Output SPSS 25}

Berdasarkan tabel diatas, nilai signifikanis menunjukkan angka 0.000, dimana angka tersebut lebih kecil dari 0.05. Maka dapat disimpulkan bahwa variabel independen pada penelitian ini yaitu likuiditas dan solvabilitas berpengaruh signifikan secara simultan terhadap variabel dependennya yaitu profitabilitas.

\section{Koefisien Determinasi (Adjusted R Squared)}

Pengujian koefisien determinasi dilakukan untuk mengetahui seberapa besar variabel independen dapat menjelaskan variabel dependennya. Berikut adalah tabel untuk melihat hubungan antara variabel independen dengan variabel dependen serta besarnya suatu variabel independen dalam menjelaskan variabel dependen:

\section{Tabel 9 Hasil Uji Koefisien Determinasi}

\section{Model Summary ${ }^{b}$}

\begin{tabular}{ll|l|l|l} 
& & & \\
Model & $\mathrm{R}$ & R Square & Adjusted R Square & $\begin{array}{l}\text { Std. Estimate } \\
\text { Estim of the }\end{array}$ \\
\hline 1 & $.689^{\mathrm{a}}$ & .474 & .439 & .031317 \\
\hline
\end{tabular}

a. Predictors: (Constant), X2, X1 


\section{b. Dependent Variable: Y}

\section{Sumber : Data Output SPSS 25}

Dari tabel diatas ditunjukkan nilai Adjusted $R$ Square adalah sebesar 0.439. Hal ini menunjukkan bahwa nilai koefisien determinasi dari penelitian ini adalah sebesar 0.439 dimana nilai tersebut menjelaskan sebesar $43.9 \%$ variabel independen penelitian ini dapat menjelaskan variabel dependennya. Sisanya sebesar $56.1 \%$ dapat dijelaskan oleh variasi variabel lain yang tidak diteliti dalam penelitian ini.

1. Pengaruh Likuiditas terhadap Profitabilitas

Hasil uji t yang dilakukan terhadap variabel likuiditas menghasilkan nilai $\mathrm{T}_{\text {hitung }}$ sebesar 2,056, nilai $\mathrm{T}_{\text {tabel }}$ sebesar 1,697, dan nilai signifikan sebesar 0,049. Hal ini menunjukkan bahwa nilai signifikansi lebih kecil dari $\alpha=0,05$, maka dapat disimpulkan bahwa terdapat pengaruh signifikan variabel likuditas terhadap variabel profitabilitas. Hal ini berarti semakin besar cash ratio maka diindikasikan profitabilitasnnya akan semakin meningkat. Profitabilitas yang besar yaitu menunjukkan semakin besar kemampuan perusahaan untuk memenuhi kewajiban jangka pendeknya atau likuiditasnya semakin baik. Dengan meningkatnya likuditas, dapat meningkatkan kredibilitas perusahaan yang menimbulkan reaksi positif dari para investor untuk berinvestasi.

2. Pengaruh Solvabilitas terhadap Profitabilitas

Hasil uji t yang dilakukan terhadap variabel solvabilitas menghasilkan nilai $\mathrm{T}_{\text {hitung }}$ sebesar $-1,015$, dan nilai $\mathrm{T}_{\text {tabel }}$ sebesar 1,697, dan nilai signifikan sebesar 0,318. Karena tingkat signifikan lebih besar dari $\alpha=0,05$, maka tidak terdapat pengaruh signifikan variabel solvabilitas terhadap variabel profitabilitas. Hal ini menunjukkan bahwa semakin meningkatnya debt to asset ratio maka akan diikuti dengan kenaikan profitabilitasnya.

Apabila perusahaan mempunya solvabilitas yang tinggi, maka perusahaan akan mempunyai resiko kerugian yang besar, tetapi juga mempunyai kesempatan memperoleh laba dari penanam modal.

\section{SIMPULAN DAN SARAN}

\section{Simpulan}

Berdasarkan pada data yang telah dikumpulkan dalam pengujian yang telah dilakukan terhadap 33 sampel dengan menggunakan model regresi linear berganda. Hasil pengujian dan pembahasan pada bagian sebelumnya dapat diringkas sebagai berikut:

1. Rasio Likuiditas yaitu Cash Ratio mempunyai pengaruh signifikan terhadap profitabilitas yaitu Net Profit Margin yang ditunjukkan dengan nilai signifikan lebih kecil dari 0,05 yaitu sebesar 0,049 .

2. Rasio Solvabilitas yaitu Debt to asset ratio tidak mempunyai pengaruh signifikan terhadap profitabilitas yaitu Net Profit Margin yang ditunjukkan dengan nilai signifikan lebih besar dari 0,05

Saran: yaitu sebesar 0,318 .

1. Disarankan untuk memperpanjang periode dalam melakukan penelitian.

2. Disarankan menggunakan variabel independen lain untuk menggantikan variabel yang dinilai tidak mempengaruhi profitabilitas.

DAFTAR PUSTAKA :

2019, Bisnis Ritel Mpdern Ditarget Tumbuh 10\% -Ekonomi Bisnis.com.

Alamsyah. (2019). PENGARUH EFISIENSI, KUALITAS AKTIVA, LIKUIDITAS, SENSITIVITAS DAN SOLVABILITAS TERHADAP ROA PADA BANK SWASTA NASIONAL NON DEVISA. Institut Pesantren KH. Abdul Chalim.

Brigham, Eugene F, J. F. (2014). Dasar-dasar Manajemen Keuangan. Salemba Empat.

Dewi, S. (2016). Pengaruh Penggunaan Laba dan Arus Kas Terhadap Kondisi Financial Distress. EJurnal Riset Manajemen Pp.111-123. Prodi Manajemen Fakultas Ekonomi Unisma: Malang.

DINAMIKA PEKEMBANGAN SEKTOR RITEL. (n.d.). 
Ghozali, I. (2018). Aplikasi Analisis Multivariate dengan Program IBM SPSS 25. Badan Penerbit Universitas Diponegoro.

Gunawan. (2019). PENGARUH AKTIVITAS, SOLVABILITAS DAN UKURAN PERUSAHAAN TERHADAP PROFITABILITAS PERUSAHAAN MANUFAKTUR SUB SEKTOR MAKANAN DAN MINUMAN DI BURSA EFEK INDONESIA TAHUN 2012 - 2017. Program Studi Magister Manajemen Universitas Tarumanagara.

Hadya. (2018). Analisis Likuiditas, Solvabilitas dan Nilai Pasar dan Pengaruhnya terhadap Return Saham pada Perusahaan Sektor Perbankan di Indonesia. Program Studi Manajemen, Universitas Ekasakti. Hanafi, Mamduh, M., dan Halim, A. (2016). Analisis Laporan Keuangan. Edisi Kelima. UPP STIM YKPN.

Harahap, S. S. (2013). Analisa Kritis atas Laporan Keuangan. PT Raja Grafindo Persada.

Hery. (2016). Analisis Laporan Keuangan. Grasindo.

Hery, S. (2015). Analisis Kinerja Manajemen. Gramedia Widiasarana.

Ijudien. (2018). Pengaruh Stabilitas Keuangan, Kondisi Industri dan Tekanan Eksternal Terhadap

Kecurangan Laporan Keuangan. 2.

Irham Fahmi. (2015). Pengantar Manajemen Keuangan Teori dan Soal Jawab. Alfabeta.

Itsnaini, H., \& Subardjo, A. (2017). Pengaruh Profitabilitas dan Solvabilitas terhadap Nilai Perusahaan yang Dimoderasi Corporate Social Responsibility. Jurnal Ilmu Dan Riset Akuntansi.

Jaunanda. (2015). ANALISIS PENGARUH RASIO LIKUIDITAS, RASIO PROFITABILITAS, RASIO SOLVABILITAS DAN RASIO PASAR TERHADAP RETURN SAHAM. Studi Pada Perusahaan Manufaktur Yang Terdaftar Di Bursa Efek Indonesia Periode 2011 - 2013.

Kartika. (2020). Laporan Arus Kas: Pengertian, Cara Pembuatan \& Contohnya. https://www.jurnal.id/id/blog/laporan-dan-contoh-arus-kas/

Kasmir. (2014). Analisis Laporan Keuangan, Edisi Pertama, Cetakan Ketujuh. PT Raja Grafindo Persada.

Kasmir. (2017). Analisis Laporan Keuangan. PT Raja Grafindo Persada.

Kieso. (2015). Pengantar Akuntansi berbasis IFRS. Salemba Empat.

POTENSI BISNIS MINIMARKET 2019, PERKEMBANGAN RITEL. (n.d.).

Purwaji, A., Wibowo, \& Arif, A. (2016). Pengantar Akuntansi 2. Penerbit Salemba Empat.

Puspitasari. (2019). Analisis Pengaruh Rasio Likuiditas, Solvabilitas, Aktivitas dan Size Perusahaan Terhadap Kinerja Keuangan Perusahaan. Program Pasca Sarjana Fakultas Ekonomi Dan Bisnis Universitas Mercu Buana.

Santoso, S. (2016). Panduan Lengkap SPSS Versi 23. Elekmedia Computindo.

Sugiyono. (2017). Metodologi Penelitian Bisnis Cetakan 8. Cv Alfabeta.

Sunyoto, D. (2016). Metodologi Penelitian Akuntansi. PT Refika Aditama.

Utami, N. W. (2019). Jenis-jenis Laporan Keuangan Dalam Akuntansi. https://www.jurnal.id/id/blog/2017-jenis-jenis-laporan-keuangan-dalam- akuntansi/

Wolk, et al. (2013). Signaling, Agency Theory, Accounting Policy Choice. Accounting and Business Research.

Yusron. (2019). Pengertian Hipotesis. https://belajargiat.id/hipotesis/

https://id.tradingview.com/markets/stocks-indonesia/sectorandindustry-sector/retail-trade/industries/ 